\title{
ЛЕГИТИМНОСТЬ ПОЛИЦИИ
}

\author{
М.П. Клеймёнов 1,2 , М.В. Седельцев ${ }^{3}$ \\ ${ }^{1}$ Омский государственный университет им. Ф.М. Достоевского, г. Омск, Россия \\ ${ }^{2}$ Новосибирский государственный университет экономики и управления, г. Новосибирск, Россия \\ ${ }^{3}$ Омская областная коллегия адвокатов, г. Омск, Россия
}

\section{Информация о статье}

Дата поступления -

13 марта 2021 г.

Дата принятия в печать -

20 июня 2021 г.

Дата онлайн-размещения -

20 сентября 2021 г.

\section{Ключевые слова}

Легитимность полиции, полицейская провокация, коррупция, незаконный приказ, профессионализм, Россия

\section{POLICE LEGITIMACY}

Выявляются критерии легитимности полиции и причины ее делегитимации. Отмечается, что центральным звеном легитимности полиции выступает общественное доверие, признание, ведущее к сотрудничеству народа и власти. Оценки легитимности формируются на основе изучения общественного мнения - официальной процедуры мониторинга. Такое изучение в принципе должно устанавливать «проблемные зоны» деятельности полиции, имеющие отношение к нарушениям законности, насилию, жестокому обращению, провокациям, побуждению в прямой или косвенной форме кого-либо к совершению противоправных действий, иным должностным злоупотреблениям. Делается вывод, что официальный мониторинг общественного мнения о деятельности полиции, как минимум, должен дополняться результатами независимых правовых и социологических исследований, нацеленных на установление этих «проблемных зон».

\section{Mikhail P. Kleymenovi,2, Mikhail V. Sedeltsev ${ }^{3}$ \\ ${ }^{1}$ Dostoevsky Omsk State University, Omsk, Russia \\ ${ }^{2}$ Novosibirsk State University of Economics and Management, Novosibirsk, Russia \\ ${ }^{3}$ Omsk Regional Bar Chamber, Omsk, Russia}

\section{Article info \\ Received - \\ 2021 March 13 \\ Accepted - \\ 2021 June 20 \\ Available online - \\ 2021 September 20}

\section{Keywords}

Legitimacy of the police, police provocation, corruption, illegal order, professionalism, Russia
The subject of the article is assessment of public confidence in the police and the legality of its activities by the opinion of the Russian population.

The purpose of the research is to identify the reasons that affect the assessment of the police legitimacy, its perception by the population. The authors also dare to identify the role of "problem areas" of police activity (related to different violations of the law) in people assessment.

The methodology of the research includes: sociological survey among Russians, comparative criminological, statistical, hermeneutic methods, expert assessments.

The main result, scope of applications. The central link of the police legitimacy is public trust, recognition, leading to the cooperation between the people and the authorities. Legitimacy assessments are formed based on the study of public opinion - the official monitoring procedure. The website of the Russian Ministry of Internal Affairs provides information on the results of monitoring public opinion about the activities of the police, but an analysis of its content allows us to note its superficiality and unconvincing optimism. This is obviously affected by the shortcomings of the departmental legal regulation of the process of monitoring public opinion about the activities of the police, which, judging by the questionnaire questions (there are only three of them), is rather imitative in nature. We believe that the official monitoring of public opinion on the activities of the police, at a minimum, should be supplemented by the results of independent sociological studies aimed at establishing "problem areas" of police activity related to violations of the law, violence, ill-treatment, provocations, inducing someone, directly or indirectly, to commit illegal actions, other official abuses. Otherwise, the regulatory requirements for the activities of the police, which establish the foundations of its legitimacy, cannot be fully implemented. The survey of 362 citizens conducted by the authors allows to state that, with a fairly high assessment 
of the activities of the Russian police, respondents pay attention to the existence of such problems as: the lack of transparency of police activities and the presence of formal and informal means of evading the legality of police activity, the tolerance of justice authorities to police lawlessness, intoxication with power by police officers, the impact of police brutality on social and legal despair, violation of the law in the name of achieving its falsely understood goals. The extreme case of perverted official zeal is the execution of illegal orders. There are quite widespread ideas in public opinion that entrepreneurs often become victims of extortion by the police, that the police take bribes from medium and small businesses, that you can buy off police officers. At the same time, the results of the study indicate that a significant part of the population is determined to cooperate with the police. Conclusions. The public demand for the police is relevant, the honor and main meaning of which is to protect the interests of all people and serve justice. People need such policemen who will demonstrate not strength and power, but simple human complicity. This is the main secret of the legitimacy of the police. Another secret lies in the orientation of personnel policy towards professionals in the police: their selection, training and support in difficult situations.

\section{1. Введение}

Чрезвычайно высокая емкость содержания понятия легитимности и многозначность его толкования [1] заставляет уточнить его понимание по отношению к такому федеральному органу исполнительной власти в сфере внутренних дел, как полиция. Если обратиться к тексту действующего Федерального закона "О полиции», то становится очевидным, что легитимность полиции означает, во-первых, ее правовой фундамент и, во-вторых, принципы ее деятельности, к которым отнесены (1) соблюдение и уважение прав и свобод человека и гражданина, (2) законность, (3) беспристрастность, (4) открытость и публичность, (5) общественное доверие и поддержка граждан, (6) взаимодействие и сотрудничество, (7) использование достижений науки и техники, современных технологий и информационных систем ${ }^{1}$. Однако в этом перечне следует выделить главное, обозначить бесспорные аксиологические приоритеты в общепризнанной ценностной шкале участников правоотношений. По мнению Р. Уордена и С. Маклин, легитимность полиции есть общественное доверие к полиции и осознанное обязательство подчиняться ей [2, р. 42]. Иными словами, центральным звеном легитимности полиции выступает общественное доверие, признание, ведущее к сотрудничеству народа и власти [3]. Действительно, такая идея пронизывает практическое содержание всех указанных принципов, утверждающее, в частности, что:

- сотруднику полиции запрещается прибегать к пыткам, насилию, другому жестокому или унижаю- щему человеческое достоинство обращению - сотрудник полиции обязан пресекать действия, которыми гражданину умышленно причиняются боль, физическое или нравственное страдание (1);

- сотруднику полиции запрещается подстрекать, склонять, побуждать в прямой или косвенной форме кого-либо к совершению противоправных действий (2);

- граждане, общественные объединения и организации имеют право в порядке, установленном законодательством Российской Федерации, получать достоверную информацию о деятельности полиции, а также получать от полиции информацию, непосредственно затрагивающую их права, за исключением информации, доступ к которой ограничен федеральным законом (3);

- федеральный орган исполнительной власти в сфере внутренних дел проводит постоянный мониторинг общественного мнения о деятельности полиции, а также мониторинг взаимодействия полиции с институтами гражданского общества; результаты указанного мониторинга регулярно доводятся до сведения государственных и муниципальных органов, граждан через средства массовой информации, информационно-телекоммуникационную сеть «Интернет» (4).

\section{2. Методология}

На сайте МВД России выкладывается информация о результатах мониторинга общественного мнения о деятельности полиции, но анализ содержания таковой позволяет отметить ее поверхностность и

\footnotetext{
1 Федеральный закон от 7 февраля 2011 г. № 3-Ф3 «О полиции» (ред. от 24 февраля 2021 г.) // Российская газета. 2011. 8, 10 февр.; 2021. 26 февр.
} 
неубедительную оптимистичность ${ }^{2}$. Здесь, очевидно, сказываются недостатки ведомственного правового регулирования процесса мониторинга общественного мнения о деятельности полиции, который, судя по вопросам анкеты (их всего три), имеет скорее имитационный характер ${ }^{3}$. К тому же так называемый мониторинг практически нацелен на установление положительных изменений, нежели на выявление негативизмов [4].

Таким образом, можно сформулировать четыре промежуточных вывода:

А. Центральным звеном легитимности полиции выступает общественное доверие.

В. Оценки легитимности формируются на основе изучения общественного мнения.

С. Такое изучение должно в обязательном порядке устанавливать «проблемные зоны» деятельности полиции, имеющие отношение к нарушениям законности, насилию, жестокому обращению, провокациям, побуждению в прямой или косвенной форме кого-либо к совершению противоправных действий, иным должностным злоупотреблениям.

D. Из этого, в свою очередь, следует, что официальный мониторинг общественного мнения о деятельности полиции, как минимум, должен дополняться результатами независимых социологических исследований. В противном случае нормативные требования к деятельности полиции, устанавливающие основы ее легитимности, не могут быть в полной мере реализованы.

\section{3. Общие оценки работы полиции}

Такое исследование осуществлено нами в январе-апреле 2021 г. ${ }^{4}$ На вопрос: «Как, по Вашему мнению, работает сегодня полиция, как она справляется со своими обязанностями?» - получены следующие ответы (в \%):

а) отлично - 3,7;

б) хорошо - 23,7;

в) удовлетворительно - 58,5;

г) плохо - 12,4;

д) очень плохо - 1,7

\footnotetext{
${ }^{2}$ См., напр.: «Результаты социологических опросов в период 2016-2020 гг. свидетельствуют об устойчивом ежегодном позитивном росте (от 3 до 6 \%) значений показателей оценки гражданами Российской Федерации деятельности полиции». - Общественное мнение // МВД России: офиц. сайт. URL: http://мвд.рф/publicopinion.
}

Как видим, оценки в целом положительные, а тот факт, что число респондентов, оценивших работу полиции высоко, в два раза превышает количество их оппонентов, вселяет уверенность в объективности полученной информации. Такая оговорка необходима для того, чтобы избежать упреков в предвзятости при рассмотрении других ответов, которые указывают на проблемы, имеющие отношение к легитимности полиции.

В этой связи важно обратить внимание на ассоциации, которые вызывают у населения слова «полиция», «полицейский». По результатам проведенного опроса выделяются два ассоциативных ряда позитивный и негативный (табл. 1).

Таблица 1

Ассоциации респондентов на слова «полиция», «полицейский»

\begin{tabular}{|l|c|l|c|}
\hline Положительнье & $\%$ & \multicolumn{1}{|c|}{ Отрицательные } & $\%$ \\
\hline Закон и порядок & 26,9 & Беспредел, беззаконие & 10,4 \\
\hline $\begin{array}{l}\text { Справедливость, } \\
\text { беспристрастность }\end{array}$ & 11,7 & $\begin{array}{l}\text { Злоупотребление вла- } \\
\text { стью }\end{array}$ & 16,2 \\
\hline Защищенность & 19,1 & Коррумпированнность & 15,7 \\
\hline Всего & $\mathbf{5 7 , 7}$ & Всего & $\mathbf{4 2 , 3}$ \\
\hline
\end{tabular}

\section{4. Отрицательные оценки}

Понятно, что наше внимание привлекают прежде всего показатели второго ассоциативного ряда, поскольку именно они указывают на то, что общественное доверие к полиции невозможно при наличии высоких значений отрицательных характеристик. Не подлежит сомнению, что искоренению в первую очередь подлежит беззаконие. Анализу этой проблемы уделено много зарубежных публикаций, в которых фиксируется непрозрачность деятельности полиции и наличие формальных и неформальных средств уклонения от парадигмы законности служебной деятельности [5], пределы толерантности органов юстиции и гражданского общества к полицейскому беззаконию [6], различие между законностью и справедливостью [7], феномен упоения властью сотрудниками полиции [8], влияние фактов жестокости со стороны полиции на социальное и

3 Приказ МВД РФ от 1 декабря 2016 г. «Об организации постоянного мониторинга общественного мнения о деятельности полиции». URL: https://мвд.pф/upload/site1/ document_news/temp/_1550068456_8322/Ob_organizacii_ postoyannogo_monitoringa_obschestvennogo.docx.

${ }^{4}$ Опрошено 362 чел., которые по социально-демографическим признакам в целом репрезентируют социальный состав населения г. Омска. 
юридическое отчуждение [9], цинизм правового поведения полицейских, привлекаемых к ответственности за акты беззакония [10], нарушение закона во имя достижения его целей [11].

Многие из этих отрицательных явлений видны в материалах уголовного дела по обвинению оперуполномоченных уголовного розыска одного из отделов полиции УМВД по г. Новосибирску Беспалова С.В. и Петросяна И.А., задержавших без достаточных оснований гражданина N. Они применили к последнему специальные средства ограничения подвижности - браслеты наручные, застегнув их на запястьях у него за спиной, поместили его в служебный автомобиль и стали требовать добровольно признаться в совершении преступления, которого тот не совершал. Поскольку потерпевший отказался оговорить себя, то Беспалов С.В. и Петросян И.А. стали его избивать. Избиения продолжились в отделе полиции, куда был доставлен задержанный, причем они носили характер пытки. Сотрудники полиции затыкали потерпевшему органы дыхания, поднимали скованные за спиной руки вверх, имитируя дыбу, били его ногами, обутыми в тяжелую зимнюю обувь. В процессе предварительно расследования они не были арестованы, давали заведомо ложные показания, заявляя, что у потерпевшего было оружие, из которого он якобы произвел выстрел при задержании. Вину свою не признали. Несмотря на это и на групповой характер деяния, предусмотренного ст. 286 Уголовного кодекса (далее - УК) РФ «Превышение должностных полномочий», суд вынес исключительно гуманное решение, назначив каждому из подсудимых наказание в виде лишения свободы на срок 3 года и 6 месяцев условно, с лишением права занимать должности в органах внутренних дел, связанные с осуществлением функций представителя власти, на срок 2 года5 5

В приговоре суда отразились практически все перечисленные проблемы, имеющие отношение к легитимности полиции: упоение властью, граничащее с садизмом, цинизм правового поведения полицейских на предварительном следствии и в судебном заседании, поразительная толерантность органов юстиции к полицейскому беззаконию, нарушение закона якобы во имя достижения его целей.

\section{5. Ложно понятые интересы службы}

В цитируемом судебном приговоре указаны мотивы совершения преступления: «...исходя из ложного понимания истинных интересов службы в полиции, с целью мнимого раскрытия преступления, возник совместный преступный умысел, направленный на превышение должностных полномочий, т. е. совершение действий, явно выходящих за пределы их полномочий ${ }^{6}$. Характерно, что такие ложно понятые интересы службы связаны с совершением и других уголовных правонарушений: привлечением заведомо невиновного к уголовной ответственности или незаконным возбуждением уголовного дела (ст. 299), принуждением к даче показаний (ст. 302), фальсификацией доказательств и результатов оперативно-разыскной деятельности (ст. 303). Характерно и то, что уголовное преследование за два из них практически полностью отсутствует (табл. 2). Что касается применения ст. 303 УК РФ «Фальсификация доказательств и результатов оперативно-разыскной деятельности», то оно также отличается исключительным гуманизмом: за 10 лет к реальному лишению свободы осуждены 38 человек, или 3,9 \% от числа всех осужденных за это преступление за указанный период.

$$
\text { Таблица } 2
$$

Число осужденных за преступления в сфере правосудия, мотивируемые ложно понятыми интересами службы, за 2011-2020 гг.

\begin{tabular}{|c|c|c|c|c|c|c|c|c|c|c|}
\hline $\begin{array}{c}C m . \\
\mathrm{Y} K \\
P \Phi\end{array}$ & $\stackrel{2}{D}$ & $\frac{\sim}{\sim}$ & $\stackrel{m}{\stackrel{\sim}{\sim}}$ & $\frac{⿱ 亠 乂}{D}$ & $\frac{n}{2}$ & $\stackrel{\wp}{\stackrel{\overbrace{}}{\sim}}$ & $\frac{N}{0}$ & $\frac{\infty}{\stackrel{v}{0}}$ & $\frac{D}{\stackrel{v}{D}}$ & $\underset{\sim}{\underset{\sim}{⿰}}$ \\
\hline 299 & 1 & 1 & 0 & 1 & 0 & 5 & 0 & 0 & 1 & 1 \\
\hline 302 & 0 & 2 & 2 & 0 & 0 & 0 & 0 & 0 & 0 & 0 \\
\hline 303 & 50 & 76 & 85 & 94 & 73 & 100 & 124 & 115 & 129 & 129 \\
\hline
\end{tabular}

Ложно понятые интересы службы приобретают воистину извращенный характер, когда начинаются гонки за показателями («палками»), которые должны показать результаты работы сотрудников полиции в плане активной деятельности и высокой раскрываемости преступлений. Делается это просто: регистрируется очевидное правонарушение, осуществляется несложное дознание, материалы дела передаются в суд и выносится обвинительный приговор. Речь в данном случае идет о применении ст. 319 УК РФ «Оскорбление представителя власти». Как правило, такое оскорбление выражается в нецензурной брани преступника, находящегося в состоянии алкогольного опьянения, в отношении со-

\footnotetext{
${ }^{5}$ Дело № 1-160/2017 архива Дзержинского районного суда г. Новосибирска.
} 
трудников полиции во время исполнения ими должностных обязанностей по охране общественного порядка7, что закономерно ставит вопрос о том, насколько велика общественная опасность деяния. При этом полицейские сами нередко ведут себя грубо и бесцеремонно, на что указали 65,6 \% опрошенных нами граждан. Иными словами, они нередко провоцируют своим поведением ответную грубость в виде оскорбления. При этом нельзя забывать, что в России существует административная ответственность за оскорбление - ст. 5.61. Кодекса об административных правонарушениях РФ, которая предусматривает штрафные санкции. Реализации административных мер вполне достаточно для достижения целей защиты авторитета представителя власти. Вместо этого судебная практика идет по пути умножения числа ранее судимых лиц: за оскорбление представителя власти в 2011 г. осуждены 8608 чел., в 2012 г. - 7 821, в 2013 г. - 7 672, в 2014 г. 8 851, в 2015 г. - 7 816, в 2016 г. - 10 051, в 2017 г. 10 342, в 2018 г. - 10 154, в 2019 г. - 9 189, в 2020 г. 8379 чел. Таким образом, ежегодно от 8 до 10 тыс. чел. получают судимость, что пятнает не только их биографию, но и биографию близких им людей. Иначе как карательным такое уголовно-правовое реагирование не назовешь, и это закономерно подрывает легитимность не только полиции, но и правосудия. На фоне полной или частичной декриминализации оскорбления (ст. 130 УК РФ), побоев (ст. 116 УК РФ) уголовная ответственность за оскорбление представителя власти выглядит анахронизмом. Это понимают многие судьи, поэтому дела по ст. 319 УК РФ часто прекращаются (около $10 \%$ ), а в ряду назначаемых наказаний преобладает штраф. Можно также заметить, что для некоторых сотрудников полиции ст. 319 УК РФ «Оскорбление представителя власти» является своего рода искушением, провоцируя их на создание конфликтных ситуаций во время охраны общественного порядка. Не случайно такие преступления составляют более половины $(58,4$ \%) в структуре деяний посягающих на личность полицейских [12, с. 12]. Обращает на себя внимание также, что некоторые регионы России характеризуются заметно более высокой интенсивностью правоприменения в плане реализации данной уголовно-правовой нормы по сравнению со среднестатистическими

\footnotetext{
${ }^{7}$ См., напр.: Дело № 1-389/2011 (Ленинский районный суд г. Владивостока); Дело № 1-19/2014 (Пролетарский районный суд г. Ростова-на-Дону); Дело № 1-62/2012 (Данковский городской суд Липецкой области); Дело № 1-18/2014
}

показателями, что является косвенным свидетельством сложившейся практики решения типичных конфликтных ситуаций между гражданами и полицией карательными средствами. Как показывают произведенные нами расчеты, к регионам, где наиболее высок риск быть привлеченным к уголовной ответственности за оскорбление полицейского, относятся Москва, Санкт-Петербург, Московская, Архангельская, Брянская, Воронежская, Калужская, Ивановская, Тульская, Вологодская, Калининградская, Астраханская, Ростовская, Волгоградская, Самарская, Саратовская, Нижегородская, Тюменская, Кемеровская области, Ставропольский, Краснодарский, Красноярский края, Дагестан, Башкортостан, Татарстан.

\section{6. Пресечение карательной практики}

В этой связи настоятельно требуется декриминализировать уголовную ответственность за оскорбление представителя власти [13, с. 229; 14, с. 52]. С одной стороны, у сотрудников полиции, которые а) заявляют об их оскорблении и б) проводят дознание по уголовным делам, предусмотренным ст. 319 УК РФ, освободится время для выполнения более важной работы. С другой стороны, у тысяч граждан Российской Федерации, которые не знакомы с изнанкой уголовной юстиции, их родственников и знакомых не будет повода усомниться в легитимности деятельности полиции.

7. Проблема выполнения незаконных прика30в

Крайним случаем извращенного служебного рвения выступает выполнение незаконных приказов. В общественном мнении сложилась довольно представительная убежденность в реальности такого явления. Так, суждение: «Полицейские нередко выполняют незаконные приказы и готовы это делать» - респонденты оценили следующим образом (в \%):

а) категорически не согласен - 8,8;

б) скорее не согласен, чем согласен 10,8;

в) затрудняюсь ответить - 31,8;

г) скорее согласен, чем не согласен - 33,9;

д) полностью согласен - 14,7.

Как видим, число согласившихся с приведенным суждением более чем в два раза превышает количество не согласных с ним.

(Нагатинский районный суд г. Москвы); Дело № 1-1120/ 2015 (Кузьминский районный суд г. Москвы); Дело № 1386/2015 (Лефортовский районный суд г. Москвы). 
Следует учесть, во-первых, что незаконные приказы могут быть законными по форме, но незаконными по существу. Речь здесь идет о действиях сотрудников полиции, участвующих в реализации судебных решений, вынесенных без достаточных к тому оснований. Такие решения, как правило, выражают вовлеченность судей в рейдерские захваты и попирают конституционный принцип независимости судей [15-18]. Вопиющим примером такого «законного беззакония» является рейдерский захват Среднеуральского женского монастыря 8 [19], который может рассматриваться как основание для обращения в соответствующие инстанции о нарушении ст. 14 Конституции РФ, которая устанавливает: «1. Российская Федерация - светское государство. Никакая религия не может устанавливаться в качестве государственной или обязательной. 2. Религиозные объединения отделены от государства и равны перед законом». С теоретической точки зрения подобные ситуации включены в сферу анализа феномена «преступного закона» [19], а в нравственном аспекте они тяжким бременем ложатся на совесть правоприменителей, поскольку при этом появляются невинные жертвы, буквально вопиющие о справедливости. А все мы являемся свидетелями событий, которые возвращают нас к вечным вопросам бытия о смысле жизни и высокой цене «слезинки ребенка» [20].

Ситуации другого рода связаны с выполнением сотрудниками полиции заведомо незаконных приказов. Вот что написал один из респондентов (имеющий опыт работы в оперативных подразделениях органов внутренних дел) на страницах анкеты: «Незаконные приказы в деятельности полиции весьма распространены. Выполнять таковые сотрудникам полиции зачастую попросту приходится, поскольку в противном случае они рискуют попасть в немилость к вышестоящему руководству, что в дальнейшем может привести к увольнению и даже привлечению (путем “подстав") к уголовной ответственности. Встречаются и такие случаи, когда полицейские осознанно и с удовольствием выполняют незаконные приказы. По большей части, это происходит, когда есть возможность совместного (с руководителем, отдавшим приказ) незаконного заработка». При этом нужно помнить, что над головой сотрудника поли-

\footnotetext{
8 Епархия прокомментировала выселение монахинь из Среднеуральского монастыря // Правда УрФО. 14 апр., 2021. URL: https://pravdaurfo.ru/novost/eparhiya-prokommentirovala-vyselenie-monahin-iz-sredneuralskogo-monastyrya/.
}

ции, подобно дамоклову мечу, висит угроза уголовной ответственности за неисполнение приказа (ст. 286.1 УК РФ). Понятно, что законодатель в диспозиции этой нормы, по существу, определяет ограничительные условия ее реализации, имеющие отношение к признакам приказа, субъективной стороне преступления и его последствиям [21; 22], однако это не снимает вопросов исполнения незаконных приказов, отданных устно или в расчете на правовое невежество подчиненных.

\section{8. Полицейские провокации}

Результаты проведенного нами опроса зафиксировали убежденность в распространенности иных негативизмов в полицейской практике. Так, по поводу суждения: «В деятельности полиции распространена практика провокации преступлений в виде подбрасывания наркотиков гражданам» - респонденты высказались следующим образом (в \%):

а) категорически не согласен - 4,5;

б) скорее не согласен, чем согласен - 15,5;

в) затрудняюсь ответить - 31,5;

г) скорее согласен, чем не согласен - 33,8;

д) полностью согласен - 14,7.

Полученные результаты (50 \% выразивших согласие респондентов против $20 \%$ несогласных) говорят сами за себя. При этом они вполне согласуются с данными иных социологических исследований. Так, опрос «Левада-центра», проведенный в связи с «делом Ивана Голунова», показал, что 66 \% россиян считают подбрасывание полицейскими наркотиков обычной практикой ${ }^{9}$. Делается это как для «улучшения показателей служебной деятельности», так и с целью организованного вымогательства [23]. В таких условиях следует согласиться с предложениями установить уголовную ответственность за провокацию преступления [24; 25].

\section{9. Полицейская коррупция}

В общественном мнении довольно широко распространены представления о том, что предприниматели нередко становятся жертвами вымогательства со стороны полицейских (41,2 \% ответов), что полицейские «крышуют» средний и мелкий бизнес $(41,8 \%)$, что от сотрудников полиции можно откупиться (58,6 \%). Противоположные мнения высказываются в два раза реже, что указывает на тенденцию

9 «Дело Ивана Голунова» // Левада-Центр: Аналит. центр Юрия Левады. 09.07.2019. URL: ttps://www.levada.ru/ 2019/07/09/delo-ivana-golunova/. АНО «Левада-Центр» внесена в реестр некоммерческих организаций, выполняющих функции иностранного агента. 
формирования в целом негативного имиджа полиции. Эта тревожная тенденция выражает процесс делигимитизации полиции, в основе которого находится как объективный фактор - коррупция, так и субъективный - возрастающая убежденность в том, что сотрудники полиции защищают интересы власти, а не народа. Треть респондентов $(28,2 \%)$ согласилась с утверждением, что милиция служила народу, а полиция защищает интересы господствующего класса.

Полицейская коррупция вносит существенный вклад в социальную дезорганизацию [26; 27]. В соответствии с материалами научных исследований, доверие больше всего процветает в обществах с эффективной, беспристрастной и справедливой бюрократией уличного уровня (street-level bureaucracies) [28], где полицейским отводится одна из ведущих ролей. Именно поэтому наряду с антикоррупционными мерами важно обеспечить адекватный ответ на растущие общественные ожидания диалога власти с населением [29].

Как показывают результаты нашего исследования, значительная часть населения настроена на сотрудничество с полицией. На вопрос: «Готовы ли вы принять участие в охране общественного порядка?» - треть респондентов (31,6 \%) ответила положительно, причем каждый третий из них готов это делать безвозмездно. Таким образом, у полиции еще есть солидный кредит доверия, который необходимо использовать.

\section{0. Заключение}

В зарубежных исследованиях обращается внимание на ухудшение отношений между полицией и гражданами в ходе движения за права человека и массовых демонстраций против жестокости полиции, а также против продолжающейся дискриминационной практики сотрудников полиции в отношении представителей этнических меньшинств [30], на актуальность общественного запроса на полицию, честью и главным смыслом деятельности которой является защита интересов всех людей и служение справедливости [31].

Аналогичный общественный запрос зафиксирован и результатами проведенного нами опроса населения. На вопрос: «Какие факторы являются определяющими, на Ваш взгляд, при формировании положительного имиджа полиции и ее сотрудников?» - получены такие ответы (в \%, у респондентов была возможность дать несколько вариантов ответа): а) героизация деятельности в СМИ, публикация только позитивной информации - 8,2;

б) опровержение негативной информации, контроль за социальными сетями - 10,8;

в) юридическое консультирования сериалов «про бандитов и ментов» - 5,4;

г) взаимодействие с независимыми общественными органами, структурами гражданского общества - 16,9;

д) защита интересов граждан, оказание им помощи в любых критических ситуациях - 55,7;

е) иное $-3,0$.

Как видим, люди нуждаются в таких полицейских, которые будут демонстрировать не силу и власть, а простое человеческое соучастие. Именно в этом заключается главный секрет легитимности полиции.

Другой секрет заключается в ориентации кадровой политики на профессионалов в полиции: их подбор, подготовку и поддержку в трудных ситуациях. Характерно, что в периоды смут, потрясений и реформ от профессионалов избавляются, их меняют на послушных дилетантов. Хотя при этом много говорится о необходимости подготовки профессионалов, обладающих «мудростью Соломона, храбростью Давида, терпением Иакова и добротой самаритянина» [32, с. 245]. Зарубежные исследователи обращают внимание на важность определения приоритетов в конфликтных полицейских стратегиях (предупреждение vs репрессия, общественное согласие vs утверждение установленного порядка), которое зависит от выбора позиции участия полицейских сил на какой-либо стороне («правых» или «левых» в политической борьбе), на значимость роли полицейских профсоюзов при определении такой позиции. При этом они усматривают различия между ценностными ориентациями различных моделей правосознания полицейских - репрессивной и превентивной. Для представителей первой модели в большей степени характерны готовность к арестам правонарушителей, обеспечение уважения к закону, взаимодействие с другими силовыми структурами и магистратами, упор на применение санкций в системе юстиции. Представители превентивной модели профессионального правосознания отличаются ориентацией на защиту демократических институтов, борьбу с бедностью и безработицей, партнерство с гражданским обществом. Однако и те, и другие одинаково оценивают важность борьбы с экстремизмом, бандитизмом, проституцией, наркотизмом [33, 
р. 347-348, 357-358]. Для обеспечения «минимального стандарта» легитимности российской полиции необходимо просто воспитание честного полицейского и создание условий для его профессиональной деятельности, что означает наличие уважительного отношения к нему со стороны руководства и отсутствие интриг в профессиональной среде. Позвольте авторам выразить убежденность, основанную на собственном опыте и опыте многих коллег, что таких проблем в советской милиции не было. Капитализм создает "универсального полицейского", образ которого - «человек-маска», а маска, как известно, сопровождает карнавал, который всегда кончается.

\section{СПИСОК ЛИТЕРАТУРЫ}

1. Носов С. И. Легитимность и легальность как правовые категории / С. И. Носов // Юрист. - 2020. - № 8. С. 43-49. - DOI: 10.18572/1812-3929-2020-8-43-49.

2. Worden R. Mirage of Police Reform: Procedural Justice and Police Legitimacy / R. Worden, S. McLean. University of California Press, 2017. - xii, 254 p. - DOI: 10.1525/luminos.30.

3. Лозовская С. В. Роль выборов в обеспечении легитимности государственной власти / С. В. Лозовская // Государственная власть и местное самоуправление. - 2020. - № 11. - C. 41-45. - DOI: 10.18572/1813-12472020-11-41-45.

4. Тимко С. А. Новая процедура мониторинга общественного мнения о деятельности полиции: критический взгляд / С. А. Тимко // Вестник Сибирского юридического института МВД России. - 2017. - № 2 (27). С. 70-75. - DOI: 10.51980/2542-1735_2017_2_70.

5. Sekhon N. Police and Limit of Law / N. Sekhon // Columbia Law Review. - 2019. - Vol. 119, no. 6. - P. $1711-$ 1772.

6. Thaman S. Constitutional Rights in the Balance: Modern Exclusionary Rules and the Toleration of Pjlice Lawlessness in the Search for Truth / S. Thaman // The University of Toronto Law Journal. - 2011. - Vol. 61, no. 4. P. 691-735.

7. Meares T. Lawful or Fair? How Cops and Laypeople Perceive Good Policing / T. Meares, T. Tyler, J. Gardener // Journal of Criminal Law and Criminology. - 2015. - Vol. 105, no. 2. - P. 297-343.

8. Adler J. "The Greatest Thrill I Get is When I Hear a Criminal Say, 'Yes, I Did it": Race and the Third Degree in New Orleans, 1920-1945 / J. Adler // Law and History Review. - 2016. - Vol. 34, no. 1. - P. 1-44.

9. McLemore B. Procedural Justice, Legal Estrangement and the Black People's Grand Jury / B. McLemore // Virginia Law Review. - 2019. - Vol. 105, no. 2. - P. 371-395.

10. Hagan J. Dual-process theory of racial isolation, legal cynicism, and reported crime / J. Hagan, B. McCarthy, D. Herda, A. C. Chandrasekher // Proceedings of the National Academy of Sciences of the United States of America. 2018. - Vol. 115, no. 28. - P. 7190-7199. - DOI: 10.1073/pnas.17222/10115.

11. Joh E. E. Breaking the Law to Enforce It: Undercover Police Participation in Crime / E. E. Joh // Stanford Law Review. - 2009. - Vol. 62, no. 1. - P. 155-198.

12. Кузьмин А. В. Уголовно-правовая охрана личности сотрудников правоохраниительных органов : дис. ... канд. юрид. наук / А. В. Кузьмин. - Ставрополь, 2015. - 226 с.

13. Филиппов П. А. Преступления против порядка управления: теоретико-правовые проблемы и доктринальная модель уголовного закона : дис. ... д-ра юрид. наук / П. А. Филиппов. - М., 2015. - 621 с.

14. Клейменов М. П. Полицейский произвол: мифы и реальность / М. П. Клейменов // Всероссийский криминологический журнал. - 2021. - Т. 15, № 1. - С. 46-54. - DOI: 10.17150/2500-4255.2021.15(1).46-54.

15. Лошкарев В. В. Прокурор в системе противодействия незаконным финансовым операциям с использованием судебных решений / В. В. Лошкарев // Законность. - 2018. - № 9. - С. 16-18.

16. Роганов С. А. Проблемы применения норм преюдиции в уголовном процессе при производстве по уголовным делам в сфере экономической деятельности / С. А. Роганов, А. Б. Старокоров // Ленинградский юридический журнал. - 2017. - № 4. - С. 139-148.

17. Абашева Ф. А. Усмотрение судьи при принятии им решений, вытекающих из гражданских правоотношений в порядке ст. 90 УПК РФ / Ф. А. Абашева // Российский судья. - 2017. - № 6. - С. 24-26.

18. Гирько С. И. Вопросы злоупотребления правилами подведомственности и подсудности при рассмотрении гражданских дел / С. И. Гирько, И. В. Ильин // Современный юрист. - 2018. - № 2. - С. 17-24. 
19. Кондраткова Н. В. К вопросу о противодействии рейдерству в России / Н. В. Кондраткова, В. С. Дмитриевский // Российский следователь. - 2020. - № 9. - С. 32-36. - DOI: 10.18572/1812-3783-2020-9-32-36.

20. Криницин А. Б. Миф о жертве в поздних романах Ф.М. Достоевского / А. Б. Криницин // Litera. 2016. - № 2. - C. 56-70. - DOI: 10.7256/2409-8698.2016.2.19126.

21. Бриллиантов А. О признаках приказа, неисполнение которого сотрудником органа внутренних дел влечет уголовную ответственность (ст. 286.1 УК) / А. Бриллиантов // Уголовное право. - 2012. - № 4. - С. 1721.

22. Кудрявцев П. А. Генезис понятия приказа, его применение и ответственность за неисполнение в российском законодательстве / П. А. Кудрявцев // Юридический мир. - 2014. - № 5. - С. 45-50.

23. Поляков С. Б. Условия российской правовой системы для заказных уголовных дел / С. Б. Поляков // Адвокат. - 2009. - № 5. - С. 68-78.

24. Иванов В. Д. Провокация преступления / В. Д. Иванов, В. А. Черепахин // Российский следователь. 2013. - № 14. - С. 29-32.

25. Борков В. Н. Провокация преступления: уголовно-правовая оценка действий провокатора и спровоцированного / В. Н. Борков // Законы России: опыт, анализ, практика. - 2019. - № 6. - С. 68-74.

26. Bayley D. Police Corruption: What Past Scandals Teach about Current Challenges : Research Report / D. Bayley, R. Perito. - US Institute of Peace, 2011. - 20 p.

27. Dordevich S. Collection on Policy on Police Reform in Serbia : Research Report / S. Dordevich, J. Litavski. Belgrade Centre for Security Policy, 2012. -40 p.

28. Rothstein B. The State and Social Capital: An Institutional Theory of Generalized Trust / B. Rothstein, D. Stolle // Comparative Politics. - 2008. - Vol. 40, no. 4. - P. 441-459.

29. Holston J. "Come to the Street!": Urban Protest, Brazil 2013 / J. Holston // Anthropological Quarterly. 2014. - Vol. 87, no. 3. - P. 887-900.

30. Kocak D. Rethinking Community Policing in International Police Reform: Examples from Asia / D. Kocak. Ubiquity Press : Geneva Centre for the Democratic Control of Armed Forces, 2018. - 68 p.

31. Gaub F. Relationship Therapy: Making Arab Police Reform Work / F. Gaub, A. Walsh. - Paris : European Union Institute for Security Studies (EUISS), 2020. - 62 p.

32. Хазова В. Е. Современные тенденции подготовки полицейских кадров в XXI веке / В. Е. Хазова, Е. Ю. Сергеева // Вестник Московского университета МВД России. - 2013. - № 7. - С. 243-246.

33. Coulangeon Ph. Professional Ideologies: A Latent Class Analysis of Police Officers' Opinions on the Role of the Police / Ph. Coulangeon, G. Pruvost, I. Roharik, T. Matthews // Revue française de sociologie (English Edition). 2012. - Vol. 53, no. 3. - P. 347-380.

\section{REFERENCES}

1. Nosov S.I. Legitimacy and legality as legal categories. Yurist = Jurist, 2020, no. 8, pp. 43-49. DOI: 10.18572/1812-3929-2020-8-43-49. (In Russ.).

2. Worden R., McLean S. Mirage of Police Reform: Procedural Justice and Police Legitimacy. University of California Press, 2017. xii + 254 p. DOI: 10.1525/luminos.30.

3. Lozovskaya S.V. The role of elections in securing legitimacy of the government. Gosudarstvennaya vlast' $i$ mestnoe samoupravlenie $=$ State Power and Local Self-government, 2020, no. 11, pp. 41-45. DOI: 10.18572/18131247-2020-11-41-45. (In Russ.).

4. Timko S.A. A new procedure for monitoring public opinion of policing: a critical view. Vestnik Sibirskogo yuridicheskogo instituta MVD Rossii = Vestnik of Siberian Law Institute of the MIA of Russia, 2017, no. 2 (27), pp. 7075. DOI: 10.51980/2542-1735_2017_2_70. (In Russ.).

5. Sekhon N. Police and the limit of the law. Columbia Law Review, 2019, vol. 119, no. 6, pp. 1711-1772.

6. Thaman S. Constitutional Rights in the Balance: Modern Exclusionary Rules and the Toleration of Pjlice Lawlessness in the Search for Truth. University of Toronto Law Journal, 2011, vol. 61, no. 4, pp. 691-735.

7. Meares T., Tyler T., Gardener J. Lawful or Fair? How Cops and Laypeople Perceive Good Policing. Journal of Criminal Law and Criminology, 2015, vol. 105, no. 2, pp. 297-343. 
8. Adler J. "The Greatest Thrill I Get is When I Hear a Criminal Say, 'Yes, I Did it": Race and the Third Degree in New Orleans, 1920-1945. Law and History Review, 2016, vol. 34, no. 1, pp. 1-44.

9. McLemore B. Procedural Justice, Legal Estrangement and the Black People's Grand Jury. Virginia Law Review, 2019, vol. 105, no. 2, pp. 371-395.

10. Hagan J., McCarthy B., Herda D, Chandrasekher A.C. Dual-process theory of racial isolation, legal cynicism, and reported crime. Proceedings of the National Academy of Sciences of the United States of America, 2018, vol. 115, no. 28, pp. 7190-7199. DOI: 10.1073/pnas.17222/10115.

11. Joh E.E. Breaking the Law to Enforce It: Undercover Police Participation in Crime. Stanford Law Review, 2009, vol. 62, no. 1, pp. 155-198.

12. Kuz'min A.V. Criminal and legal protection of the personality of employees of law enforcement agencies, Cand. Diss. Stavropol, 2015. 226 p. (In Russ.)

13. Filippov P.A. Crimes against the order of management: theoretical and legal problems and the doctrinal model of criminal law, Doct. Diss. Moscow, 2015. 621 p. (In Russ.)

14. Kleymenov M.P. Abuse of power by the police: myths and reality. Vserossiiskii kriminologicheskii zhurnal = Russian Journal of Criminology, 2021, vol. 15, no. 1, pp. 46-54. DOI: 10.17150/2500-4255.2021.15(1).46-54. (In Russ.).

15. Loshkarev V.V. A public prosecutor in the system of countering illegal financial transactions with usage of court resolutions. Zakonnost', 2018, no. 9, pp. 16-18. (In Russ.).

16. Roganov S.A., Starokorov A.B. Problems of applying the norms of prejudice in criminal proceedings in criminal cases in the sphere of economic activity. Leningradskii yuridicheskii zhurnal, 2017, no. 4, pp. 139-148. (In Russ.).

17. Abasheva F.A. Judicial discretion at making judgments resulting from civil-law relations in order of Article 90 of the Criminal Procedure Code of the Russian Federation. Rossiiskii sud'ya=Russian Judge, 2017, no. 6, pp. 24-26. (In Russ.).

18. Girko S.I., Ilin I.V. Revisiting the issues of abuse of subject matter and court jurisdiction rules with the civil procedures. Sovremennyi yurist, 2018, no. 2, pp. 17-24. (In Russ.).

19. Kondratkova N.V., Dmitrievskiy V.S. On raidership combating in Russia. Rossiiskii sledovatel' = Russian Investigator, 2020, no. 9, pp. 32-36. DOI: 10.18572/1812-3783-2020-9-32-36. (In Russ.).

20. Krinitsyn A.B. The Myth of Sacrifice in Dostoevsky's Later Novels. Litera, 2016, no. 2, pp. 56-70. DOI: 10.7256/2409-8698.2016.2.19126. (In Russ.).

21. Brilliantov A.V. Criteria for the order, failure to which the employee body of internal affairs entails criminal liability. Ugolovnoe pravo, 2012, no. 4, pp. 17-21. (In Russ.).

22. Kudryavtsev P.A. Genesis of the concept of the order, application and responsibility for failure to perform in the Russian legislation. Yuridicheskii mir = Juridical World, 2014, no. 5, pp. 45-50. (In Russ.).

23. Polyakov S.B. Conditions of the Russian legal system for ordered criminal cases. Advokat, 2009, no. 5, pp. 68-78. (In Russ.).

24. Ivanov V.D., Cherepakhin V.A. Provocation of a crime. Rossiiskii sledovatel' = Russian Investigator, 2013, no. 14 , pp. 29-32. (In Russ.).

25. Borkov V.N. Provocation of crime: criminal law assessment of actions provocateur and provoked. Zakony Rossii: opyt, analiz, praktika, 2019, no. 6, pp. 68-74. (In Russ.).

26. Bayley D., Perito R. Police corruption: What Past Scandals Teach about Current Challenges, Research Report. US Institute of Peace, 2011. 20 p.

27. Dordevich S., Litavsky J. Collection on Policy on Police Reform in Serbia, Research Report. Belgrade Centre for Security Policy, 2012. 40 p.

28. Rothstein B., Stolle D. The State and Social Capital: An Institutional Theory of Generalized Trust. Comparative Politics, 2008, vol. 40, no. 4, pp. 441-459.

29. Holston J. "Come to the Street!": Urban Protest, Brazil 2013. Anthropological Quarterly, 2014, vol. 87, no. 3, pp. 887-900.

30. Kocak D. Rethinking Community Policing in International Police Reform: Examples from Asia. Ubiquity Press, Geneva Centre for the Democratic Control of Armed Forces, 2018. 68 p.

31. Gaub F., Walsh A. Relationship Therapy: Making Arab Police Reform Work. Paris, European Union Institute for Security Studies (EUISS), 2020. 62 p. 
32. Hazova V.E., Sergeyeva E.Yu. Current trends of vocational training of police shots in the XXI century. Vestnik Moskovskogo universiteta MVD Rossii, 2013, no. 7, pp. 243-246. (In Russ.).

33. Coulangeon P., Pruvost G., Roharik I., Matthews T. Professional Ideologies: A Latent Class Analysis of Police Officers' Opinions on the Role of the Police. Revue française de sociologie (English Edition), 2012, vol. 53, no. 3, pp. 347-380.

\section{ИНФОРМАЦИЯ ОБ АВТОРАХ}

Клеймёнов Михаил Петрович - доктор юридических наук, профессор, заслуженный деятель науки Российской Федерации, ${ }^{1}$ заведующий кафедрой уголовного права и криминологии, ${ }^{2}$ профессор кафедры уголовного права и национальной безопасности

${ }^{1}$ Омский государственный университет им. Ф.М. Достоевского

${ }^{2}$ Новосибирский государственный университет экономики и управления

${ }^{1}$ 644077, Россия, г. Омск, пр. Мира, 55а

2 630099, Россия, г. Новосибирск, ул. Каменская, 56

E-mail: klim798@mail.ru

ORCID: 0000-0002-6942-7059

SPIN-код РИНЦ: 4431-6452; AuthorID: 596245

Седельцев Михаил Владимирович - кандидат юридических наук, адвокат

Омская областная коллегия адвокатов 644001, Россия, г. Омск, ул. Лермонтова, 127/1

E-mail: siberianbear2008@yandex.ru

РИнц AuthorID: 524123

\section{БИБЛИОГРАФИЧЕСКОЕ ОПИСАНИЕ СТАТЬИ}

Клеймёнов М.П. Легитимность полиции / М.П. Клеймёнов, М.В. Седельцев // Правоприменение. - 2021. - T. 5, № 3. - C. 34-44. - DOI: 10.52468/2542-1514.2021.5(3).34-44.

\section{INFORMATION ABOUT AUTHORS}

Mikhail P. Kleymenov - Doctor of Law, Professor, Honoured Scientist of the Russian Federation; ${ }^{1}$ Head Department of Criminal Law and Criminology; ${ }^{2}$ Professor, Department of Criminal Law and National Security

${ }^{1}$ Dostoevsky Omsk State University

${ }^{2}$ Novosibirsk State University of Economics and Management

${ }^{1}$ 55a, Mira pr., Omsk, 644077, Russia

2 56, Kamenskaya ul., Novosibirsk, 630099, Russia

E-mail: klim798@mail.ru

ORCID: 0000-0002-6942-7059

RSCI SPIN-code: 4431-6452; AuthorID: 596245

Mikhail V. Sedeltsev - PhD in Law, advocate Omsk Regional Bar Chamber

127/1, Lermontova ul., Omsk, 644001, Russia

E-mail: siberianbear2008@yandex.ru

RSCl AuthorID: 524123

\section{BIBLIOGRAPHIC DESCRIPTION}

Kleymenov M.P., Sedeltsev M.V. Police legitimacy. Pravoprimenenie $=$ Law Enforcement Review, 2021 , vol. 5, no. 3, pp. 34-44. DOI: 10.52468/2542-1514. 2021.5(3).34-44. (In Russ.). 